\title{
Aglaia mabberleyi Pannell (Meliaceae), a new species from Borneo
}

\author{
C.M. Pannell \\ Department of Plant Sciences, \\ University of Oxford, South Parks Road, \\ Oxford OX1 3RB \\ caroline.pannell@plants.ox.ac.uk \\ Royal Botanic Gardens, Kew, Richmond, \\ Surrey TW9 3AE \\ Queen's University Belfast, Marine Laboratory, \\ 12-13 The Strand, Portaferry, \\ Co Down BT22 1PF
}

ABSTRACT. Aglaia mabberleyi Pannell is described as new from Borneo. It is distinguished from Aglaia rufibarbis Ridl. under which name it has hitherto been treated.

Keywords. Aglaia rufibarbis, David Mabberley, molecular phylogeny, Peninsular Malaysia

\section{Introduction}

Forty-three years ago, while I was an undergraduate at the University of Cambridge, Professor E.J.H. Corner recommended that I approach David Mabberley - who had been Corner's last research student - to explore the possibility of becoming his first research student at Oxford. David suggested I work on the genus Aglaia Lour., the largest and taxonomically most intractable genus in the family Meliaceae. We have collaborated on the family and co-authored Flora contributions ever since.

I felt enormously privileged to be welcomed into the world of tropical botany at Oxford and to know that my D.Phil. research would be part of a wider project on economically important tropical tree families which had been initiated by the late Frank White (1927-1994), the curator of the Oxford Herbaria. The work of Pennington \& Styles (1975) provided a rigorous generic framework for the Meliaceae, and a sentence in White's introduction to that work - "It was also intended, so far as possible, to study in the field the functional significance of the floral and fruit characters used in the classification." - inspired me to embark on a year of field work exploring the reproductive biology of Aglaia in Peninsular Malaysia. It was funded by a Leverhulme Studentship from the Royal Society. When I arrived at the beginning of 1978, Ruth Kiew, who had also been a Ph.D. student of Corner's, and her then husband B.H. Kiew, took me under their wings and introduced me into life and research in Peninsular Malaysia. Engkik Soepadmo was my field supervisor at Universiti Malaya and took me to Kuala Lompat in the Krau Game Reserve (now Krau Wildlife Reserve), which became my field site for the year. During that year, a successful application for a NERC 
Special Competition Studentship provided me with two years funding to complete my D.Phil. in Oxford, supervised by David Mabberley. During the second year of that studentship, I was awarded the Claridge Druce Junior Research Fellowship in Plant Taxonomy, to write a monograph of the genus Aglaia. This made me the first woman to be offered a Fellowship at Lincoln College, Oxford. The result of that fellowship, a comprehensive monograph of Aglaia throughout its range (Pannell, 1992) has led to collaborations with phytochemists, molecular systematists, field ecologists and biogeographers, many of which are ongoing (Pannell, 2018). David and I have shared the task of revising the Meliaceae for floras in the Indo-Malayan and Australasian regions, my contribution being Aglaia. Other genera were adopted by Terry Clark (Heynea, Pseudoclausena, Walsura; see Clark, 1994) and Jennifer Edmonds (Toona; see Edmonds, 2007, 2013), while Anne Sing assisted David for many years, especially in his preparation of the revision of Dysoxylum (Mabberley et al., 1995).

\section{The new species}

In 1974, David Mabberley collected material of this new species in Sarawak. I have previously included these collections and others like them from Borneo in Aglaia rufibarbis Ridl. - a species now understood to have a more restricted distribution in Peninsular Malaysia (Pannell, 1992, 2007, 2013). The most recent molecular phylogeny of the genus (Grudinski et al., 2014) lends support to the view that the Bornean element of Aglaia rufibarbis should be recognised as a separate species. Although much of the branching in this clade is poorly supported, the Borneo plants originally included in Aglaia rufibarbis are sufficiently distinct morphologically to be recognised as a separate species requiring a new name. This species is therefore here described and named in honour of David Mabberley on the occasion of his $70^{\text {th }}$ birthday and in recognition of his long association with the taxonomy of the family Meliaceae. One of his collections is designated as the holotype.

\section{Aglaia mabberleyi Pannell sp. nov.}

Aglaia mabberleyi Pannell is distinguished from Aglaia rufibarbis Ridl. and A. tomentosa Teijsm. \& Binn. when fresh by the pale lower leaflet surface and contrasting coloration of the dark reddish-brown stellate hairs which form a dense indumentum on the midrib, lateral veins and less so on the reticulation of the lower leaflet surface. The arms of the stellate hairs are shorter than in A. rufibarbis and the leaflets are somewhat bullate when dry, whereas they are smooth in A. tomentosa, and smooth or shrivelled in A. rufibarbis. - TYPE: Malaysia, Sarawak, 1st Division, Semengoh Forest Reserve, 19 April 1974, D.J. Mabberley 1582 (holotype FHO; isotypes FHO, L, SAR) (Fig. 1-3). 


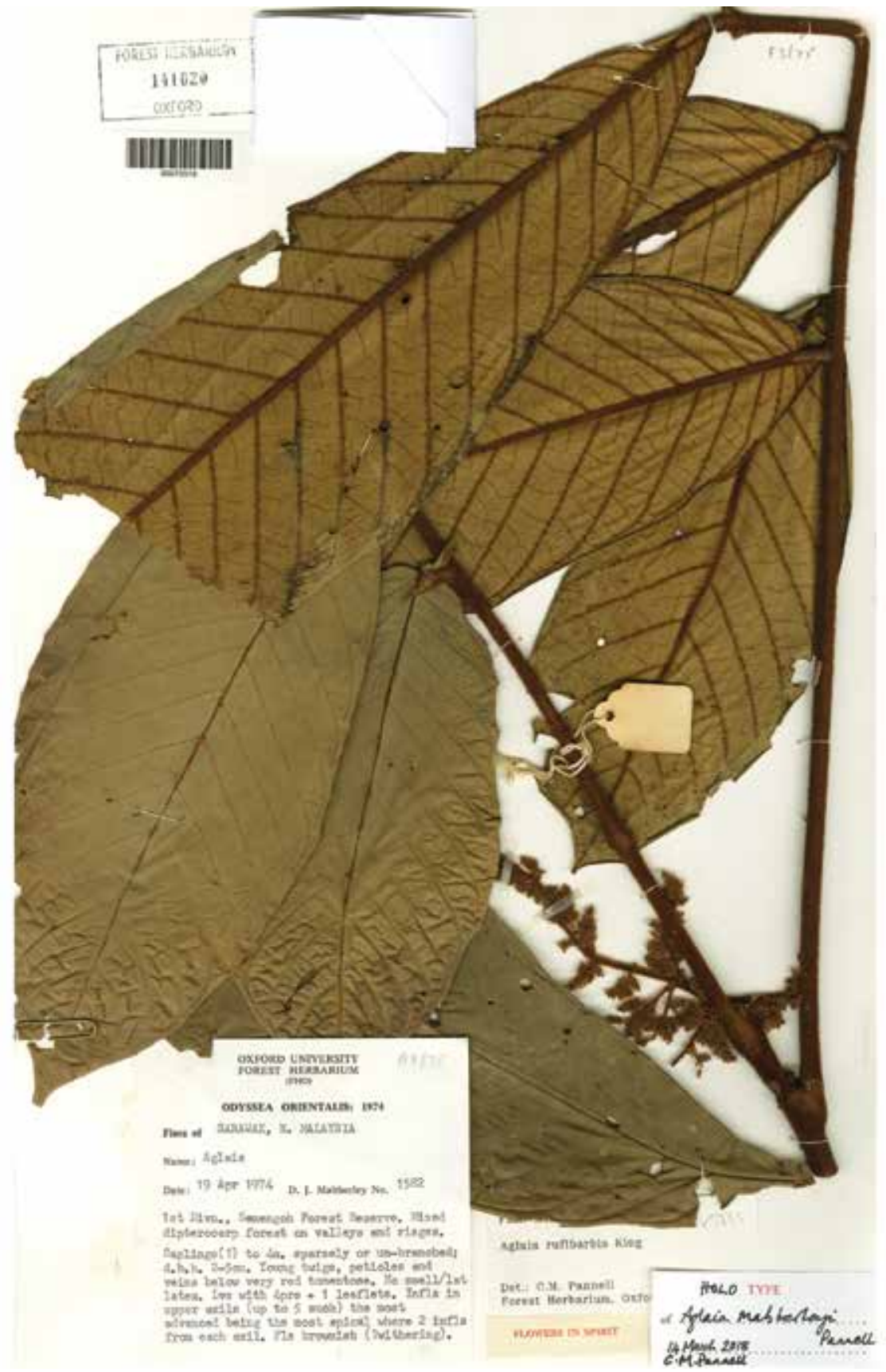

Fig. 1. Holotype specimen of Aglaia mabberleyi: Sarawak, 1st Division, Semengoh Forest Reserve, 19 April 1974, D.J. Mabberley 1582 (FHO). 
Small tree to $4 \mathrm{~m}$ tall, to $5 \mathrm{~cm}$ diameter, sparsely branched or unbranched. Bark dark brown or reddish-brown, with longitudinal cracks and small clear lenticels; inner bark brown or pale brown. Twigs densely covered with dark reddish-brown stellate hairs with arms to $2 \mathrm{~mm}$ long. Leaves imparipinnate, to $75 \mathrm{~cm}$ long; with petioles 16-36 cm long; lateral leaflets 3 or 4 on each side of rachis, opposite; blades obovate, oblanceolate or elliptical, 14-33 × 6-14 cm, margin recurved, acuminate or caudate at the apex, with the obtuse or acute acumen 5-15 mm long, tapering to a narrow asymmetrical cordate base, the proximal lobe on the lateral leaflets larger than the distal, with hairs like those on the twigs, densely covering the midrib and lateral veins and numerous on the leaflet surface in between, interspersed with dark-reddish brown 'dots'; lateral veins 10-23 on each side of midrib, ascending and curved upwards near the margin, the midrib prominent, lateral veins subprominent and intercostal veins slightly prominent below, the leaflet lamina bullate in between; leaflets subsessile or with petiolules $2-5 \mathrm{~mm}$ long. Male inflorescence to $18 \mathrm{~cm}$ long and $18 \mathrm{~cm}$ wide. Female inflorescences to $11 \mathrm{~cm}$ long and $9 \mathrm{~cm}$ wide. The peduncle, branches and pedicels densely covered with stellate hairs like those on the twigs. Male flowers minute, each subtended by a linear bract 2-3 mm long with numerous reddish-brown stellate hairs $0.5 \mathrm{~mm}$ in diameter; flower buds subglobose, c. $0.5 \mathrm{~mm}$ in diameter; pedicel c. $1 \mathrm{~mm}$ long; calyx divided to the base into 5 narrow, acute lobes c. $1.5 \mathrm{~mm}$ long with numerous stellate hairs like those on the bracts on the outer surface; petals 5 , c. $0.3 \mathrm{~mm}$ long and $0.3 \mathrm{~mm}$ wide, subrotund; staminal tube shallowly cup-shaped, anthers broadly ovoid, inserted on the margin of the tube, $0.25 \mathrm{~mm}$ long and 0.25 $\mathrm{mm}$ wide; ovary depressed globose with one empty locule, stigma subglobose c 0.15 $\mathrm{mm}$ in diameter. Female flowers slightly larger, up to $1 \mathrm{~mm}$ in diameter; subsessile or with pedicel to $0.5 \mathrm{~mm}$. Fruits indehiscent, c. $2.5-3 \mathrm{~cm}$ long and $2.3-3 \mathrm{~cm}$ wide, subglobose, with a longitudinal ridge, densely covered with stellate hairs like those on the twigs, subsessile; pericarp brittle, readily torn open, c. $1 \mathrm{~mm}$ thick, inner surface smooth, brown and shiny; locules 1 or 2 , each containing 0 or 1 seed. Seeds c. $1.5 \mathrm{~cm}$ long and $1.3 \mathrm{~cm}$ wide.

Distribution. Endemic to Borneo (Sarawak and Kalimantan). Known in Sarawak from Belaga, Bintulu, Kapit, Kuching and Miri districts, and in West Kalimantan from Sintang.

Ecology. In mixed dipterocarp forest to submontane mossy forest, to $820 \mathrm{~m}$ altitude.

Vernacular name. Kumpung penjaru (Kalimantan, Church et al. 236).

Additional specimens examined. MALAYSIA: Sarawak: 1st Division, Semengoh Forest Reserve, 19 Apr 1974 (fl), Mabberley 1631 (FHO, L, SAR); Kuching District, Arboretum, Semengoh Forest Reserve, 3 May 1961 (fl), S13663 (K, SAR); Kuching District, Arboretum, Semengoh Forest Reserve (near T.261), 30 Jan 1960 (fr), Hj. Bujang S11032 (K); Kuching District, Arboretum, Semengoh Forest Reserve, 20 Feb 1960, Anderson S9104 (SAR, SING), S10197 (SAR) \& S11032 (K); Kuching District, Arboretum, Semengoh Forest Reserve, Banyeng \& Jugah S26881 (SAR); 1st Division, Kuching, Matang, proposed Matang National 


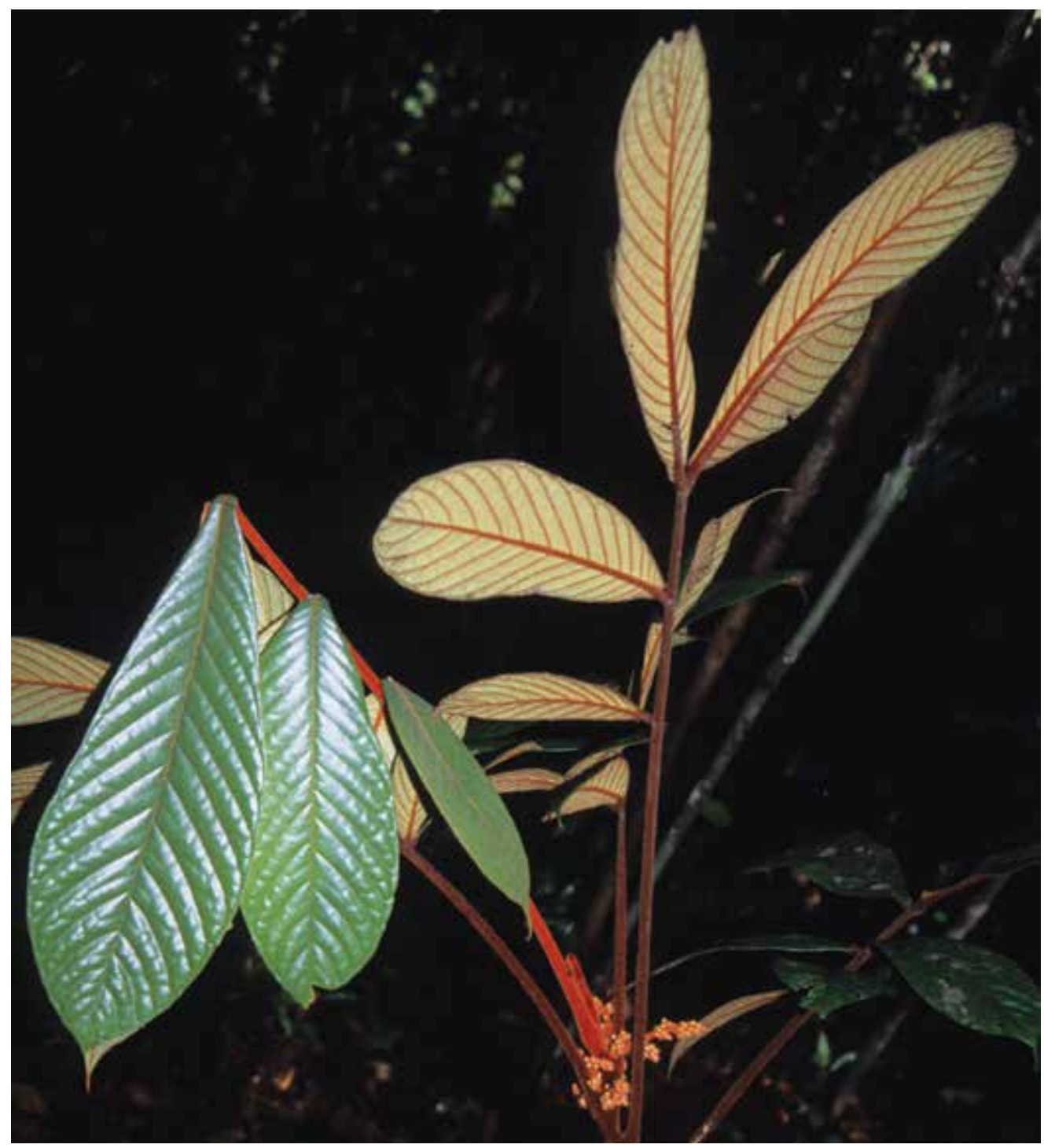

Fig. 2. Apical shoot of living plant of Aglaia mabberleyi in Semengoh Arboretum, Sarawak, showing upper and lower surfaces of leaflets and female inflorescence. (Photo: C.M. Pannell).

Park, Sg Sendok, 8 May 1987 (fl), Lee S53843 (K, KEP, L, SAR); 4th Division, Miri, Sungei Jelalong, Ketbulu Protected Forest, Sungei Arang, fl., 24 Oct 1984, Othman et al. S49152 (K, KEP, L, SAR); 7th Division, Belaga, Linau, Sg Iban, 30 Oct 1982 (young fr), Lee S45375 (K, SAR); 7th Division, Belaga, Dulit Range, Ulu S. Kayan, 20 Oct 1983 (fr), Awa \& Yii S46898 (K); 7th Division, Belaga, SG. Murum, 600m, Lai et al S68534 (KEP).

INDONESIA: West Kalimantan: Sintang, Bukit Baka National Park, Ola Saka Dua environs, c. $600 \mathrm{~m}$ up Sungai Ella, 038'S, 112 ${ }^{\circ} 17^{\prime} \mathrm{E}, 20$ Oct 1993 (fl), Church et al. 236 (A, FHO, SING); Sintang, Bukit Baka National Park, 037'S, 112 15'E, 30 Oct 1993 (fr), Church et al. 454 (FHO, SING); Bukit Mehipit, 500 m, 7 Dec 1924 (ster), Winkler 637 (BO). 


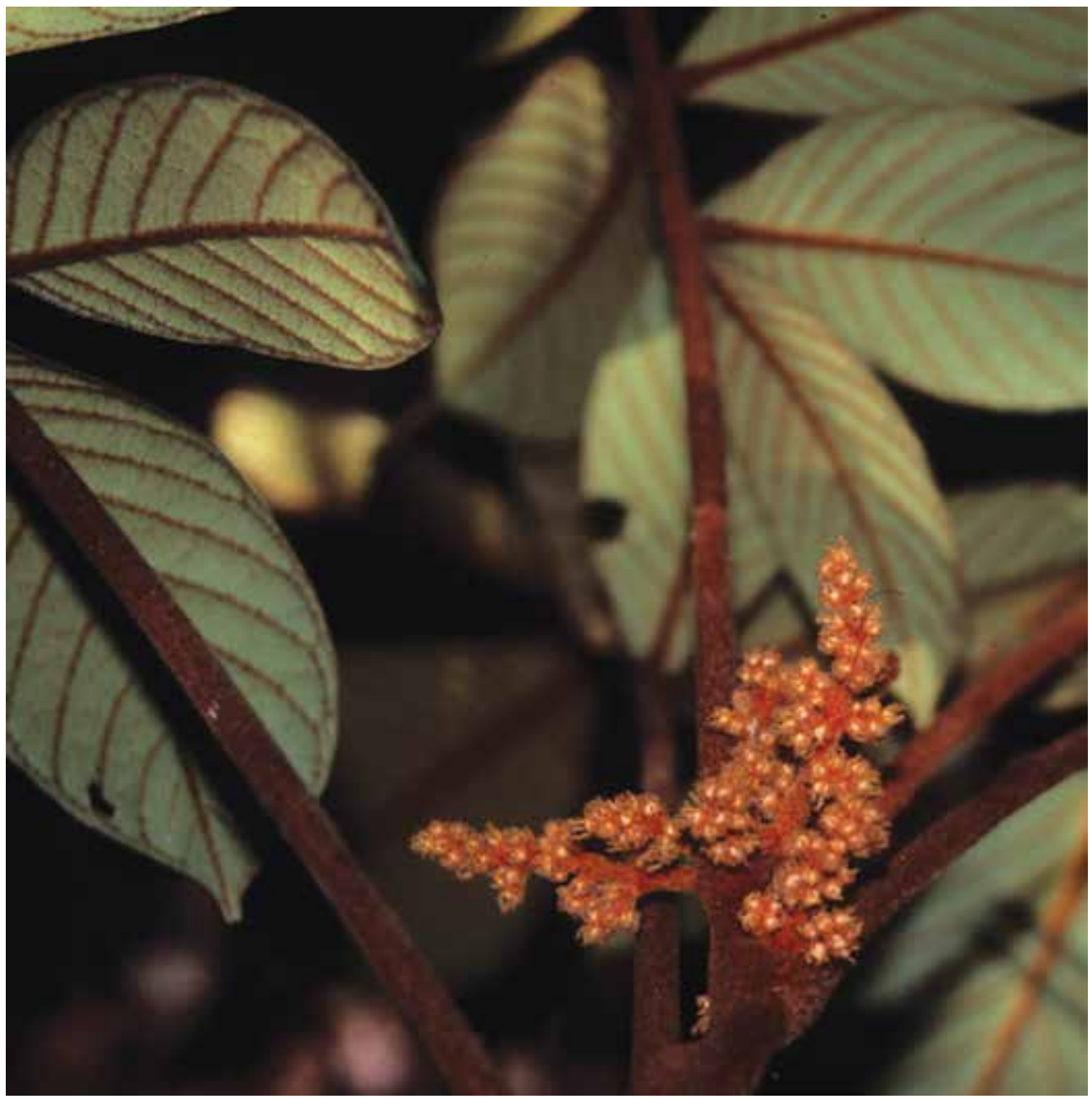

Fig. 3. Female inflorescence on living plant of Aglaia mabberleyi in Semengoh Arboretum, Sarawak. (Photo: C.M. Pannell).

ACKNOWLEDGEMENTS. I am grateful to David Mabberley for introducing me to the genus that has become my life's work and continues to present challenges and opportunities for field work, flora writing and research in molecular phylogeny, phytochemistry, ecology and historical biogeography. Engkik Soepadmo, Ruth Kiew and my assistant, Kalang bin Tot, were crucial to the success of my initial field work in 1978. Julia Sang and staff from SAR took me to Semengoh Arboretum in 2005. Thanks are due to the directors and curators of herbaria that have welcomed me to work on their collections during the preparation of this paper, including A, BO, BRUN, FHO, K, KEP, L, SAN, SAR, SING. Stephen Harris, curator of the Oxford Herbaria since 1995, has encouraged and supported my association with the Daubeny Herbarium (FHO). He has commented on the manuscript of this paper and supplied the image of the holotype. Engkik Soepadmo and Ruth Kiew have been kind and generous throughout, from my arrival in Peninsular Malaysia in 1978, until visits to FRIM during the last 15 years. 


\section{References}

Clark, T.P. (1994). The species of Walsura and Pseudoclausena genus novum (Meliaceae). Blumea 38: 247-302.

Edmonds, J.M. (2007). Toona (Meliaceae). In: Soepadmo, E., Saw, L.G., Chung, R.C.K. \& Kiew, R. (eds) Tree Flora of Sabah and Sarawak, vol. 6, pp. 198-204. Kuala Lumpur: Forest Research Institute Malaysia.

Edmonds, J.M. (2013). Toona (Meliaceae). In: Kiew, R., Chung, R.C.K., Saw, L.G. \& Soepadmo, E. (eds) Flora of Peninsular Malaysia, ser. 2, vol. 4, pp. 246-257. Kuala Lumpur: Forest Research Institute Malaysia.

Grudinski, M., Pannell, C.M., Chase, M.W., Ahmad, J.A. \& Muellner-Riehl, A.N. (2014). An evaluation of taxonomic concepts of the widespread plant genus Aglaia and its allies across Wallace's Line (tribe Aglaieae, Meliaceae). Molec. Phylogen. Evol. 73: 65-76.

Mabberley, D.J., Pannell, C.M. \& Sing, A.M. (1995). Meliaceae. Flora Malesiana, ser. 1, Seed Plants, vol. 12, pt. 1. Leiden: Foundation Flora Malesiana.

Pannell, C.M. (1992). A taxonomic monograph of the genus Aglaia Lour. (Meliaceae). Kew Bulletin Additional Series 16. London: HMSO.

Pannell, C.M. (2007). Aglaia (Meliaceae). In: Soepadmo, E., Saw, L.G., Chung, R.C.K. \& Kiew, R. (eds) Tree Flora of Sabah and Sarawak, vol. 6, pp. 24-107. Kuala Lumpur: Forest Research Institute Malaysia.

Pannell, C.M. (2013). Aglaia (Meliaceae). In: Kiew, R., Chung, R.C.K., Saw, L.G. \& Soepadmo, E. (eds) Flora of Peninsular Malaysia, ser. 2, vol. 4, pp. 54-155. Kuala Lumpur: Forest Research Institute Malaysia.

Pannell, C.M. (2018). Reproductive biology, morphological taxonomy, biogeography and molecular phylogeny of Aglaia Lour. (Meliaceae): the monographic approach to a large genus of tropical trees. Sibbaldia 16: 87-97.

Pennington, T.D. \& Styles, B.T. (1975). A generic monograph of the Meliaceae. Blumea 22: 419-540. 
